\title{
Training Transfer: A New Model in the United Arab Emirates General Education Sector-Hybridization of the Theory of Planned Behavior with the Training Transfer Model
}

\author{
Saeed Khalifa Alshaali ${ }^{1}$, Kamal Ab Hamid ${ }^{2}$ \& Ali Ali Al-Ansi ${ }^{3,4}$ \\ ${ }^{1}$ School of Business Management, College of Business, University Utara Malaysia, Malaysia \\ ${ }^{2}$ School of Accountancy, College of Business, University Utara Malaysia, Malaysia \\ ${ }^{3}$ Tunku Puteri Intan Safinaz School of Accountancy College of Business, University Utara Malaysia, Malaysia \\ ${ }^{4}$ College of Business Administration, Shaqra University, Kingdom of Saudi Arabia \\ Correspondence: Saeed Khalifa Alshaal, School of Business Management, College of Business, University Utara \\ Malaysia, Malaysia. E-mail: skalshal@gmail.com
}

Received: July 30, 2018

doi:10.5539/ies.v11n12p49
Accepted: September 1, $2018 \quad$ Online Published: November 27, 2018

URL: https://doi.org/10.5539/ies.v11n12p49

\begin{abstract}
This study investigates variables in training transfer in the general education (school) sector of the United Arab Emirates (UAE) by hybridizing the established training transfer model and the theory of planned behavior (TPB). The hybridized model employs four variables: (i) supervisor support, (ii) training design, (iii) intention to transfer, and (iv) training transfer. This model is used to test nine hypotheses. The study sample comprised 225 employees from the UAE general education sector. Study participants (respondents to a questionnaire) were recruited by simple random sampling. The study questionnaire data was analyzed using Partial least squares structural equation modeling PLS-SEM. The study model had a good fit confirming a good fit of the hypothesized model to the empirical data. Eight out of nine hypotheses were accepted. The study is generally parallel with TPB. It demonstrates that intention to transfer has a dominant and central (mediating) influence on transfer process and transfer behavior. Remarkably, supervisor support is important only in the pre-training phase. For the UAE education sector to succeed in effective training transfer, supervisors must be properly trained to design training programs, particularly to enhance the trainee's intention to apply training on the job. This study proved empirically that designing training is a critical influence of a trainee's intention to apply training. Training design and intention to transfer are mediators and play a central role in promoting the training transfer process. Future studies should focus on including TPB and intention in the training transfer researches.
\end{abstract}

Keywords: training transfer, training design, intention to transfer, supervisor support, general education sector, theory of planed behavior

\section{Introduction}

Training transfer, or application of on-the-job training, is a global concern in human resource management (Baldwin \& Ford, 1988, Baldwin, Ford, \& Blume, 2017). As such, it has attracted the attention of many researchers and training professionals (Bhatti et al., 2013). Furthermore, training transfer has become a key criterion for evaluating the effectiveness of training programs (Baldwin \& Ford, 1988).

It has been estimated that billions of dollars per year are wasted globally due to the poor application of training programs with just 10 to 27 percent of training applied properly in the workplace (Arthur et al., 2003; CIPD, 2015; Ford, 2009; Georgenson, 1982; Griffin, 2010; Industry Report, 2000). Many scholars have attempted to understand the complexities of the training transfer process to address the problem of low training application and wasted training expenditure (Baldwin \& Ford, 1988; Holton, 1996, 2005; Kavanagh, 1998; Tracey et al., 1995). Hence, this study adds to existing contributions in the field by proposing a new training transfer conceptual model that consists of four variables: (i) supervisor support, (ii) training design, (iii) intention to transfer, and (iv) training transfer.

The present study investigates training transfer using these variables by merging two established theories: (i) the training transfer model (Baldwin \& Ford, 1988) and (ii) the theory of planned behavior (TPB) (Ajzen, 1991). By 
drawing on these robust and established theories, we strive to test or contribute to the field by better understanding related components in the education sector.

This study makes a major contribution to the literature by hybridizing the training transfer model (Baldwin \& Ford, 1988 ) with the theory of planned behavior (TPB) (Ajzen, 1991); many authors have previously applied and proposed the same concept (e.g., Cheng \& Ho, 1998; Posthuma \& Dworkin, 2000; Davis, Ajzen, Saunders, \& Williams, 2002; Wiethoff, 2004; Al-Eisa, Furayyan \& Alhemoud, 2009; Cheng, Sanders, \& Hampson, 2015). Hybridization of these theories allows application of variables that are present in one model but missing in the other model to both models, for instance, variables that are unique to the TBP can be applied to the training transfer model, and vice versa. For instant, intention construct in TBP, is missing in training transfer model. Indeed, Rangel et al. (2015) confirmed that understanding intention to transfer is important for a comprehensive understanding of training transfer. Thus, a hybridized model will improve understanding of transfer behavior. This study also establishes a more precise intention items (survey questions) in the domain of training transfer domain relying on Ajzen $(2005,1991)$ who was the first to develop TPB; Ajzen psychological theories are widely regarded (Cheng and Hampson, 2008).

This study makes a major contribution to the education sector by focusing on an educational training transfer model rather than a general transfer model. The education sector in this study represents all general education (school) sector employees including managerial and specialized personnel. Hence, this study will investigate a narrow population compared to general governmental population. Thus, the proposed model will be useful for training practitioners as well as managers in the education sector.

A further contribution of this paper is the inclusion of the training design variable. Here, we assume that training design has an important effect on the intention to transfer. Gyimah (2015) stated that training design has a dominant influence on the training transfer process. Thus, training design is a necessary variable when attempting to explain study relationships. In contrast, training design reflects training content (Holton et al., 2000), and one of the main aspects of training content is to enhance intention to transfer via "trainee attitude." According to TPB, trainee attitude is a fundamental influencer of trainee intention. Training design-specific contributions are discussed in detail in the literature review section.

\section{Literature Review}

\subsection{Training Transfer}

The implementation of on-the-job-training is a major concern of institutions globally (Al-Eisa et al., 2009; Baldwin \& Ford, 1988; Baldwin et al., 2017). Following this important conclusion, Kauffeld and Lehmann-Willenbrock (2010) later found that training transfer is considered in insufficient depth in both practice and academic studies. Despite the wealth of literature findings, there are many (and often serious) inconsistencies in these findings, which limit translation to practice (Grossman \& Salas, 2011). While there have been a number of important contributions to the current training transfer literature (Baldwin et al., 2009; Blume et al., 2010; Burke and Hutchins, 2007; Cheng \& Hampson, 2008; Cheng \& Ho, 1998; Merriam \& Leahy, 2005), a detailed understanding of the training transfer process remains elusive (Grossman \& Salas, 2011).

\subsection{Intention to Transfer}

In psychology, the intention construct is recognized as a crucial agent in human behavior (Ajzen, 1991). Similarly, in the training transfer domain, Rangel et al. (2015) demonstrated that a proper understanding of intention is necessary for a comprehensive understanding of training transfer (trainee behavior at work). Intention to transfer is the first and most critical phase (as well as a precondition) for the transfer process (Al-Eisa et al., 2009; Foxon, 1994; Grohmann et al., 2014; Holton, 1996). In the broader psychological context, Ajzen (1991) argues that behavioral intentions lead to future behavior.

Future researches should consider those factors that could be modified to affect intention to transfer (Ubed, 2017). Many researchers are concerned about the trainee's intention including how and when they will apply training (Baldwin et al., 2017). Cheng and Hampson (2008) propose that trainee intention to transfer is a missing element in the existing transfer models. Despite its clear importance, intention to transfer has received inadequate examination in the current literature (Al-Eisa et al., 2009; Foxon, 1994). In addition, many TPB studies did not investigate the mediating role of intention to transfer (Cheng et al., 2015). Accordingly, this study proposed a new conceptual model that considers intention as the mediating agent in accordance with TPB.

\subsection{Supervisor Support}

Supervisor support includes many kinds of assistance activities from supervisors to their subordinates (Holton et al., 2000) before, during, and after training (Ghosh, Chauhan, \& Rai, 2015). In general, supervisor support is a 
fundamental determinant of successful training transfer (Van den Bossche \& Segers, 2013), and it is one of the most important work environment variables (Baldwin \& Ford, 1988; Cromwell \& Kolb, 2004; Kraiger et al., 2004).

Research into supervisor support generally gives contradictory and diverse results (Burke and Hutchins, 2007; Ghosh et al., 2015). Thus, this study will clarify the role of supervisor support on the training transfer process, particularly in the UAE education context. This can give more descriptions to the contradictory situation of supervisor support.

\subsection{Supervisor Support and Training Design}

Despite the fact that supervisors are the main formulators of their staff plans in the majority of cases, the training transfer model treats supervisor support and training design independently. This study suggested linking these variables. Chauhan et al. (2017) suggested that training transfer would be positively affected if supervisors focus on training design. Thus, one of the aims of this study is to study empirically the relationship between supervisor support and training design.

Chauhan et al. (2017) suggested that supervisors play a facilitatory role when they act as moderators between training design and training transfer. We will challenge that suggestion by analyzing the pre-training role of the supervisor in training design. The role of the supervisor in the pre-training phase is to establish a training design. The role during the training and post-training phase is one of moderation. It encompasses a sense of follow-up. Thus, we will consider the role of the supervisor in the pre-training phase as an 'input' to training design. Therefore, it is hypothesized that supervisor support should be an "input" to training design rather than a moderator. Although supervisors have a major role in designing training for their subordinates, only a few studies have investigated this relationship (e.g., Velada et al., 2007; Chauhan et al., 2017).

\subsection{Supervisor Support and Intention to Transfer}

The direct influence of supervisor support on trainee intention to transfer is clearly addressed in TPB via the influence of a "subjective norm" on "intention." However, supervisor support influences the trainee's intention via representation of a role model (Bandura, 1997). Accordingly, supervisor support exerts a positive influence on intention to transfer.

\subsection{Training Design}

Training design is a dominant influencer of the training transfer process (Gyimah, 2015; Nikandrou et al., 2009) making it a fundamental tool to improve trainee on-the-job competencies (Bhatti et al., 2013). Training design has two main attributes: (i) it is significantly correlated with training transfer, and (ii) it is a significant predictor of training transfer (Velada et al., 2007). Furthermore, training design is an important antecedent of transfer in all current transfer models (Baldwin \& Ford, 1988; Burke \& Hutchins, 2007; Ford \& Weissbein, 1997).

Many researchers have shown that the training design has an important and strong relationship with training transfer (Ford \& Weissbein, 1997; Grossman \& Salas, 2011; Gyimah, 2015; Nikandrou et al., 2009), although only a limited number of researchers have investigated training design in training transfer models (Bhatti et al., 2013). Baldwin et al. (2017) and Bell et al. (2017) reported that more confirmation is needed related to training design and implementations of training initiatives.

\subsection{Training Design and Intention to Transfer}

To date, no studies in the field of training transfer have investigated the relationship between training design and training intention. In psychology, TPB attempts to address how training design affects training intention by stating, "Attitude is an input to intention" (Ajzen, 1991). Therefore, a major component of training design is to change trainee attitude through well-designed content (Holton et al., 2000). Put simply, when training content is designed to improve trainee attitude toward transfer, then it is expected that the trainee's intention to transfer training is improved.

Another justification for the relationship between training design and intention to transfer is declared by TBP through the notion of "planed behavior." According to TPB, intention emerges when a person starts to plan an activity (or behavior). In general, a statement of planning (designing) mainly reflects that person's intention. To include this concept in the study proposed model, it is determined that the training design (planning) influences the training intention. Similarly, Gollwitzer (1996) stated that formulating a particular plan represents an implementation intention; this principle was confirmed by Ajzen (2009). Extending on this notion, the training design variable is proposed to be included in the current study framework. 


\section{Proposed Study Framework}

The proposed framework of the present study is largely based on Baldwin and Ford's training transfer model (1988) while adding elements from other supporting theories (TPB). Therefore, based on the theoretical gaps identified in the literature review, Figure 1 provides a schematic of the study proposed model.

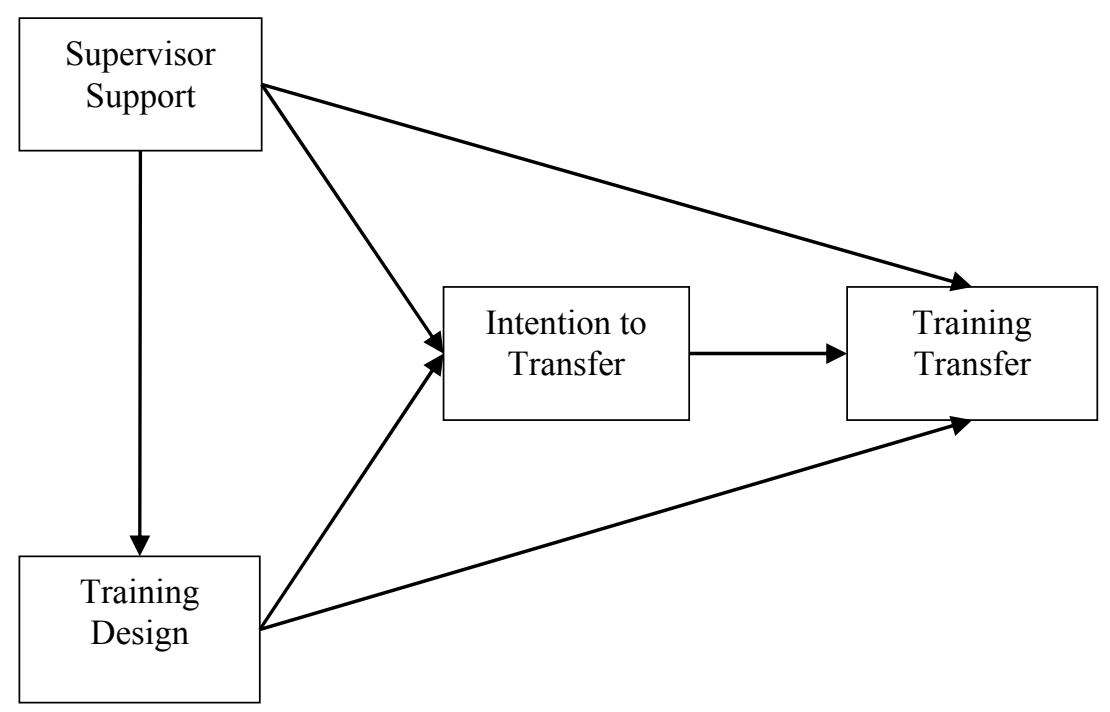

Figure 1. Proposed training transfer model

\section{Research Design and Methodology}

The "quantitative method" approach is used here because this study aimed to identify factors that influence outcomes (Creswell, 2013). This approach is appropriate in cases where there is a well-developed theory, and it is commonly used to evaluate behavior (Bryman \& Bell, 2011).

This study tests nine hypotheses (described later) and includes four variables: (i) supervisor support, (ii) training design, (iii) intention to transfer, and (iv) training transfer. These variables originate from the training transfer model, TPB and the literature review.

It is important that the study population is carefully selected to be relevant to the research (Lunenburg and Irby, 2008). This study population was made up of employees from the UAE general education sector. The employee's population was enrolled in at least one training program within a one-year period (Jun-Choi \& Park, 2014). All types of jobs are included because the main criteria of the population is training enrollment. The total study population is around fifteen thousand employees (http://www.fahr.gov.ae). According to Krejcie and Morgan (1970), in order to obtain a representative sample from a total population of fifteen thousand, 377 participants are required. However, 100 to 150 respondents are acceptable for structural equation modeling (SEM) (Schumacker \& Lomax, 2016, p. 47). Due to the behavioral (Kirkpatrick's, 1959; Kraiger, 2002) and individual nature of the study variables (e.g., intention), the "individual units" (employees) are selected (Sekaran \& Bougie, 2013) via random sampling relying on Sekaran and Bougie (2013) recommendations.

Following the literature review, and the theoretical study framework, the following hypotheses were stated:

H1. Intention to transfer has a positive effect on training transfer.

H2. Supervisor support has a positive effect on intention to transfer.

H3. Supervisor support has a positive effect on training design.

H4. Supervisor support has a positive effect on training transfer.

H5. Training design has a positive effect on intention to transfer.

H6. Training design has a positive effect on training transfer.

H7. Intention to transfer takes a mediating role between supervisor support and training transfer. 
H8. Intention to transfer takes a mediating role between training design and training transfer.

H9. Training design takes a mediating role between supervisor support and intention to transfer.

\section{Research Questionnaire}

The study questionnaire was developed with two sections: (i) demographic information and (ii) study items (questions). The questionnaire used a five-point Likert scale with the following responses: strongly disagree $=1$, disagree $=2$, neutral $=3$, agree $=4$, and strongly agree $=5$ (Jamieson, 2004; Norman, 2010). The study variables were derived and adapted from the study training transfer literature review as well from psychology (such as Ajzen, 1991). Training transfer items were mainly obtained from two key studies (Tesluk et al., 1995; Xiao, 1996), and then these items were adapted according to the results of additional studies (Bhatti et al., 2013; Blume et al., 2010; Chiaburu \& Marinova, 2005; Chiaburu, et al., 2010; Pham et al., 2013; Scaduto et al., 2008; van der Locht et al., 2013; Velada et al., 2007).

Referring to Ajzen (2005) (the TPB developer), the intention to transfer main items were initiated based on three key phrases: (i) "I intend to ...", (ii) "I plan to ...", and (iii) "I will try to ....". Additionally, two new items were added by replicating the main items (mainly from "I intend to ...") with a slight adjustment seeking more reliable results. The intention to transfer items and identifications have many diverse perspectives (see mainly: Al-Eisa et al., 2009; Bock \& Kim 2002), and thus this study relied fundamentally on Ajzen $(2005,1991)$ to gain a precise application of intention to transfer in both its identification and items. Ajzen's contribution to this field is considerable, and he is widely regarded as having established one of the most robust psychological theories (Cheng \& Hampson, 2008).

The work of Holton et al. (2000) is widely regarded as a major contribution to the identification of training design in field of training transfer (Bates, Holton \& Hatala, 2012; Bates, Kauffeld \& Holton, 2007; Khasawneh et al., 2006; Velada et al., 2007); hence, Holton et al.'s (2000) identification of training design is used in this study. Supervisor support is identified according to Holton et al. (2000) and in accordance with other leaders in the field (Govaerts \& Dochy, 2014; Holton \& Baldwin, 2003; Holton \& Bates, 1998; Pham et al., 2013). Additionally, supervisor support items were obtained mainly from Xiao (1996).

\subsection{Modification and Testing of Research Items}

Once selected, research items must be tested to ensure their suitability for the study population. Since the study items were initially expressed in the English language, a systematic and an accurate method was used to translate them into Arabic. This method consists of several testing phases (back translation): (i) forward translation (English to Arabic), and then (ii) backward translation (Arabic to English) using the standards described by Brislin (1970, 1986) and following the recommendations of Banville, Desrosiers \& Genet-Volet (2000).

After translation, a pretest was performed following Sekaran and Bougie (2013) who described pretesting as the use of a small number of respondents (focus group) to test the appropriateness of questions and their comprehension. For the study pretest, a group of five participants evaluated and reviewed the study draft questionnaire directly giving their feedback to the study researchers.

A pilot test was applied following the pretest. The aim of the pilot test is to confirm item reliability; that is, if there is internal consistency among the items (Piaw, 2012). A pilot test was performed on a small sample of employees who match the overall targeted population. The last responses collected for the pilot test consist of 30 valid questionnaires. Roscoe (1975) indicated that sample sizes bigger than 30 and below 500 are appropriate for most research. Ultimately, the result of the pilot test analysis showed that all variables items achieved acceptable reliability (Cronbach's alphas $>0.7$ ). Thus, this study identified 20 items related to the study variables via a thorough literature review, systematic language translation, and pretest and pilot test (Table 1). 
Table 1. Operational definition and study item

\begin{tabular}{|c|c|c|c|c|}
\hline Variable & Operational definition & Reference & items & Reference \\
\hline Intention to Transfer & $\begin{array}{l}\text { Trainee willingness to plan and to try to exert an } \\
\text { effort, in order to apply learnt material in the } \\
\text { workplace. }\end{array}$ & $\begin{array}{l}\text { Ajzen, 1991; Cheng and } \\
\text { Hampson, } 2015 .\end{array}$ & 5 & Ajzen, 2005. \\
\hline Supervisor Support & $\begin{array}{l}\text { The extent to which supervisors/managers support } \\
\text { and reinforce [the] use of training on the job. }\end{array}$ & $\begin{array}{l}\text { Holton et al., 2000; Bates et al., } \\
\text { 2007; Ghosh et al., 2015; Hee } \\
\text { Kim and Callahan, } 2013 .\end{array}$ & 5 & Xiao, 1996. \\
\hline Training Design & $\begin{array}{l}\text { The extent to which training is designed and } \\
\text { delivered in a manner that enables trainees to } \\
\text { transfer learning to their job. }\end{array}$ & $\begin{array}{l}\text { Holton et al., 2000; Bhatti et al., } \\
2013 .\end{array}$ & 4 & $\begin{array}{l}\text { Holton et al., } \\
\quad 2000 .\end{array}$ \\
\hline Training Transfer & $\begin{array}{l}\text { Transfer and application of knowledge, skills and } \\
\text { attitude as workplace behavior. }\end{array}$ & $\begin{array}{l}\text { Ford and Weissbein, 1997; } \\
\text { Kraiger, 2002; Al-Eisa et al., } \\
\text { 2009; Burke and Saks, } 2009 .\end{array}$ & 6 & $\begin{array}{l}\text { Tesluk et al., } \\
\text { 1995; Xiao, } \\
1996 .\end{array}$ \\
\hline
\end{tabular}

Note. The key words; "plan" and "try" of the intention to transfer identification were quoted from Ajzen (1991).

\subsection{Data Collection and Statistical Techniques}

Questionnaires were accompanied by an explanatory introduction to this study. These were emailed to all employees in the UAE Ministry of Education $(n=15,899)$. Questionnaires were sent using the employees work email addresses; this was an efficient form of questionnaire distribution and subsequent data collection, and it enabled the researchers to collect data from by a cross-sectional data collection using a random sampling method; 245 respondents completed and returned questionnaires, and 225 were valid for the final study analysis. The main exclusion criteria for completed questionnaires were: (i) respondent had not enrolled in any training within a one-year period, and (ii) incorrectly completed questionnaire.

Partial least squares structural equation modeling (PLS-SEM) analyzed the results to test the study conceptual model via its nine hypotheses, which included a mediating role (Hair, Sarstedt, Hopkins, \& Kuppelwieser, 2014; Hair, Sarstedt, Ringle, \& Mena, 2012). This is an approach that could be applied with non-normal data, small sample sizes, and the use of formative indicators (Hair et al. 2014). This analysis was performed using SmartPLS software 3.0 (Hair et al., 2014). SmartPLS is one of the prominent software applications for PLS-SEM, and the software has gained in popularity since its launch in 2005 (Wong, 2013).

\section{Results}

\subsection{Descriptive Statistics}

The descriptive statistics show the extent to which the study sample represents employee diversity. These ultimately represent the study population (Table 2). A total of 225 respondents matched the inclusion criteria of having attended at least one training program within the preceding year. Table 3 details the descriptive statistics (Mean and SD). The group of 225 respondents is small; 377 respondents were required. Thus, we discussed potential causes for the low response rate with the study coordinator in the UAE Ministry of Education, and the following barriers to study participation were identified: (i) UAE Ministry of Education employee is not sufficiently aware of the need to participate in research, and (ii) questionnaire overload of employees. In the context of these two barriers to study participation, and according to literature (Hair et al., 2016), the study group (225 respondents) was considered to be an acceptable size for PLS-SEM analysis approach; this is further supported by Schumacker and Lomax (2016, p.47) who state that a sample size of $100-150$ is sufficient for testing small models with well-behaved data. 
Table 2. Morphological information and respondent profile $(\mathrm{n}=225)$

\begin{tabular}{lc}
\hline Profile type & Details \\
\hline Ministry of Education (Study population $\mathrm{n}$ ) & 15,899 employees \\
\hline Supervisor (\%) & 43.3 \\
\hline Subordinate (\%) & 56.7 \\
\hline Training course attendance (\%) & 93 \\
\hline Bachelor's degree (\%) & 85.1 \\
\hline Master's degree (\%) & 10.4 \\
\hline PhD (\%) & 4.5 \\
\hline Technical (specialized) role (\%) & 44.6 \\
\hline Administrative role (\%) & 21.5 \\
\hline Administrative and field role (\%) & 20.0 \\
\hline Administrative and technical role (\%) & 9.2 \\
\hline Field role (\%) & 4.6 \\
\hline Male (\%) & 39 \\
\hline Female (\%) & 61 \\
\hline Mean work experience (years) & $16.6(\mathrm{Max}=38, \mathrm{Min}=1)$ \\
\hline Mean age (years) & $43.3(\mathrm{Max}=67, \mathrm{Min}=25)$ \\
\hline
\end{tabular}

\subsection{Correlations, Reliabilities and Hypothesis Testing}

Table 3 presents the correlation analysis of the study variables; all data have acceptable reliability (Cronbach's alpha $>0.70$ ). Note that data were analyzed after ensuring that discriminant validity had been established. Discriminant validity is a statistical test that ensures that questionnaire items from different variables are distinct and do not correlate to each other (Hair, Celsi, Money, Samouel, \& Page, 2016). Discriminant validity analysis (Fornell-Larcker criterion, cross-loading) was performed to eliminate inappropriate items. The recommendations of Hair et al. (2016) relating to discriminant validity were applied. Five out of 20 items were eliminated: three were training transfer variables and two were training design variables.

Table 3. Descriptive statistics, correlations, and reliabilities of variables

\begin{tabular}{ccccccc}
\hline Variable & Mean & SD & $\begin{array}{c}\text { Intention to } \\
\text { Transfer }\end{array}$ & Supervisor Support & Training Design & $\begin{array}{c}\text { Training } \\
\text { Transfer }\end{array}$ \\
\hline Intention to Transfer & 4.1 & 0.96 & $(0.95)$ & & & \\
Supervisor Support & 3.3 & 1.25 & $0.640^{*}$ & $(0.98)$ & $0.675^{*}$ & $(0.92)$ \\
Training Design & 3.5 & 1.18 & $0.555^{*}$ & 0.650 & $0.750^{*}$ & $(0.87)$ \\
Training Transfer & 3.7 & 1.14 & $0.291^{*}$ & &
\end{tabular}

Note: ${ }^{*} p$-values $<0.05 ; \alpha$ values shown in parentheses.

Hair et al. (2016) stated that model fit is a tool of judgments reflecting how well a hypothesized model structure fits the empirical data. Using the standardized root mean residual (SRMR) approach (Hair et al., 2016), the study model had a good fit $(0.041$; baseline $<0.08)$.

Eight of the nine hypotheses were accepted; $\mathrm{H} 4$ was rejected because supervisor support had a non-significant relationship with training transfer. Additionally, supervisor support has indirect effect on both training transfer and intention to transfer.

Hypotheses H7, H8, and $\mathrm{H} 9$ are related to the mediating role of the study conceptual model. Table 4 represents all details of the mediating situation of this study. 
Table 4. Mediating analysis

\begin{tabular}{|c|c|c|c|c|c|c|}
\hline \multirow{2}{*}{ No. } & \multirow{2}{*}{ Hypothesis } & \multirow{2}{*}{$\begin{array}{l}\text { Specific indirect } \\
\text { effects }\end{array}$} & \multirow{2}{*}{$t$-values } & \multirow{2}{*}{$p$-values } & \multicolumn{2}{|c|}{$\begin{array}{l}\text { Confidence intervals bias } \\
\text { corrected }\end{array}$} \\
\hline & & & & & $\begin{array}{c}2.50 \\
\%\end{array}$ & $\begin{array}{c}97.50 \\
\%\end{array}$ \\
\hline $\mathrm{H} 7$ & $\begin{array}{l}\text { Supervisor Support }->\text { Intention to Transfer }-> \\
\text { Training Transfer }\end{array}$ & 0.077 & 3.051 & 0.002 & 0.037 & 0.141 \\
\hline $\mathrm{H} 8$ & $\begin{array}{l}\text { Training Design }->\text { Intention to Transfer }->\text { Training } \\
\text { Transfer }\end{array}$ & 0.157 & 4.062 & 0.00 & 0.081 & 0.245 \\
\hline $\mathrm{H} 9$ & $\begin{array}{l}\text { Supervisor Support }->\text { Training Design }->\text { Intention } \\
\text { to Transfer }\end{array}$ & 0.374 & 8.694 & 0.00 & 0.296 & 0.454 \\
\hline
\end{tabular}

\section{Discussion}

Next, the study results were described in the light of both TPB and previous research focusing on the interactions between variables. The study analysis shows a significant and positive effect of intention to transfer on training transfer. This result is consistent with TPB (Ajzen, 1991) as well as the findings of other studies applied in the training transfer domain (Cheng et al., 2015; Friedman \& Ronen, 2015). Cheng et al. (2015), reported a significant relation between intentions to transfer on training transfer. Friedman and Ronen (2015) showed a significant relation including that the employees who form intentions to implement the training have remarkably more applications of training on the job.

The study analysis found that supervisor support has a significant relationship with intention to transfer, and this agrees with Ubed (2017) and Al-Eisa et al. (2009) with a correlation coefficient of 0.433 and 0.37 , respectively. Al-Eisa et al. (2009) who investigated the public sector rather than the education sector and calculated a correlation coefficient of 0.37 ; the study analysis calculated a higher correlation coefficient of 0.64 . Ubed (2017) examined the relation in the Ministry of Finance with a lower correlation coefficient than this study. This indicates that, supervisor support takes a stronger role in the education sector in the UAE than a general public sector and the financial sector. This difference confirms that the training transfer model should be applied in different contexts to draw more specific conclusions. Generally, TBP stated that the subjective norms (supervisor support in this study) are a main influencer of intention. This study model detailed here paralleled TBP.

The study analysis showed a significant and strongly correlated (correlation coefficient 0.67 ) relationship between supervisor support and training design. This represents remarkable causality; this result agrees with Velada et al. (2007) and Chauhan et al. (2017) who found lower effects than those of this study with correlation coefficients of 0.42 and 0.37 , respectively. Studying the influence of supervisor support on training design is a remarkable contribution to the current study. This proved that a supervisor support variable could be applied as input to training design instead of considering it to be an example of a moderating variable. The current study opens a new perspective of relation between supervisor support and training design.

Supervisor support has a non-significant relationship with training transfer. Accordingly, the role of the supervisor may concentrate on the period before training more than after training. Indeed, it is common to find that supervisor support has a contradictory relationship with training transfer in the training transfer domain (Bhatti et al. 2013; Facteau et al., 1995; Ghosh \& Rai, 2015). The (insignificant) result is consistent with other studies (Chiaburu \& Marinova, 2005; Fitzgerald, 2002; Fitzgerald \& Kehrhahn, 2003; Velada et al., 2007). The contradictory results urge researchers to investigate a specific sub-component instead of investigating the general concept of this variable (Govaerts \& Dochy, 2014). However, a recent study applied by (Govaerts, Kyndt, \& Dochy, 2018) showed that most of the specific sub-components of supervisor support were also insignificant.

The training design has a positive effect on both intention to transfer and training transfer with remarkable path coefficients of 0.55 and 0.59 , respectively. These training design results confirm the dominant influence of training design on the overall training transfer process (Gyimah, 2015; Nikandrou et al., 2009). The effect of training design on intention to transfer is consistent with TPB, and it should be noted that intention, according to TPB, is the effort of planning to perform behavior (Ajzen, 2009; Ajzen, 1991; Gollwitzer, 1996).

This study indicates that "designing training to just influence applying training" is inadequate; training design should focus on enhancing trainee intention rather than focusing only on post-training application.

A very simple way to focus on intention is to ask trainees to develop a plan that applies their training program (Friedman \& Ronen, 2015). From the TBP perspective, activity planning enhances intention to apply the planned 
activity. However, intention precedes transfer behavior, and thus it is important to design training to foster an "intention to behave" (Grohmann et al., 2014; Holton, 1996). A review of 94 studies showed that effective implementation of intention is a major factor in the successful achievement of goals. This approach fosters a strong commitment to the intended behavior (Ajzen et al., 2009; Gollwitzer \& Sheeran, 2006).

Intention to transfer and training design (Table 4) had a significant mediating effect (H7, H8, and H9). Intention to transfer has a significant mediating role between supervisor supports and training transfer (this result parallels TBP). In addition, intention to transfer has a significant mediating role between training design and training transfer. This confirmed the notion raised by TBP: Activity planning is an indicator of the intention to behave (apply training). Training design also gained a significant mediating role between supervisor support and intention to transfer (this result parallels TBP). Remarkably, training design gained the highest specific mediating (indirect) effect (0.374). Therefore, adding training design as a mediator to the study's conceptual model is a new contribution to TPB. It remarkably and practically represents the notion of "planned behavior".

\section{Managerial Implications}

Supervisors should usually take a dominant role in planning employee training (pre-training role). However, our results showed that there is no significant relationship between supervisor support and training transfer; this implies that it is not effective to concentrate the supervisory efforts at the post-training period. Additionally, supervisors should concentrate on enhancing trainee intention and attitude toward training rather than only focusing on knowledge and skill acquisition.

\section{Study Limitations}

These results cannot be generalized to other sectors because of its narrow focus on the education sector. This was intentional due to the study aim of gaining an enhanced specific understanding of the education sector. In TPB, the term "subjective norms" has a broad meaning rather than being limited to supervisor support. The subjective norms construct refers to the perceived social pressure to perform or not perform a behavior (Ajzen, 1991); for this, supervisor support partially reflects "subjective norms". It is advisable to include the effect of peer support and other environmental variables to obtain a complete representation of "subjective norms".

\section{Conclusion}

This study contributes to the theory of training transfer (Baldwin \& Ford, 1988) with specific application in the UAE general education sector. This study investigated training transfer according to specified variables in the context of merging the training transfer model (Baldwin \& Ford, 1988) with TPB (Ajzen, 1991). The results showed that the selected study variables (were applied in the training transfer context) are consistent with TPB. For instance, intention to transfer has a dominant and central influence on the proposed transfer model. In TPB, intention can be described first as something that directly affects behavior and second as a mediator between behavior and all other constructs (Ajzen, 1991). Therefore, intention to transfer in this study has the same description of TPB. Thus, we concluded that the study conceptual model is consistent with TPB.

Training design toward transfer behavior proved the main notion of TBP "planned behavior". This study proved empirically that designing training or (planning training) strongly affects intention to apply training. Supervisor support has a crucial role and is a main input of training design. This study proved that supervisor support has a direct supporting role on training design. It is not simply an agent that represents a moderating role. Thus, in order for the UAE education sector to apply their training programs successfully on the job, it should concentrate on training supervisors to build up an accurate and smart training program for their subordinates. In addition, supervisors are considered to be a model to follow from subordinates by representing good intention to transfer training to the job. Bandura (1997) termed this situation as a "role model". Therefore, supervisors should foster their subordinate's attitudes and intentions toward training transfer.

\section{Recommendations for Future Research}

Future research should seek to demonstrate the central role of intention in the training transfer model and aim to foster the inclusion of intention as a main variable in the training transfer model. Future research should also generally focus on inclusion of TPB in the training transfer model. Furthermore, the interaction between supervisor support and training design should be investigated in a range of sectors and cultures. We also recommend the inclusion of leadership theory in the training transfer models to better understand the contradictory results of supervisors on training transfer model. Studies on specific sub-components of supervisor support are also needed (Govaerts \& Dochy, 2014).

The study items (questions) can improve the study item statement. Even if this study followed all the research methodologies to translate and foster the precision of the study items, discriminant validity could not be 
established in some cases. It is recommended to retest the study items in the UAE context. Generally, this study urges other researchers to confirm our results.

\section{References}

Ajzen, I. (1991). The theory of planned behavior. Organizational Behavior and Human Decision Processes, 50(2), 179-211. https://doi.org/10.1016/0749-5978(91)90020-T

Ajzen, I., \& Fishbein, M. (2005), The influence of attitudes on behavior. In D. Albarracín, B. T. Johnson, \& M. P. Zanna (Eds.), The Handbook of Attitudes (pp. 173-221). Erlbaum, Mahwah, NJ.

Ajzen, I., Czasch, C., \& Flood, M. G. (2009). From intentions to behavior: implementation intention, commitment, and conscientiousness. Journal of Applied Social Psychology, 39(6), 1356-1372. https://doi.org/10.1111/j.1559-1816.2009.00485.x

Al-Eisa, A. S., Furayyan, M. A., \& Alhemoud, A. M. (2009). An empirical examination of the effects of self-efficacy, supervisor support and motivation to learn on transfer intention. Management Decision, 47, 1221-1244. https://doi.org/10.1108/00251740910984514

Arthur, W., Bennett, W., Edens, P. S., \& Bell, S. T. (2003). Effectiveness of training in organizations: a meta-analysis of design and evaluation features. Journal of Applied Psychology, 88, 234-245. https://doi.org/10.1037/0021-9010.88.2.234

Baldwin, T. T., \& Ford, J. K. (1988). Transfer of training: A review and directions for future research. Personnel Psychology, 41, 63-105. https://doi.org/10.1111/j.1744-6570.1988.tb00632.x

Baldwin, T. T., Ford, J. K., \& Blume, B. D. (2009). Transfer of training 1988-2008: An updated review and agenda for future research. International Review of Industrial and Organizational Psychology, 24, 41-70.

Baldwin, T. T., Ford, J. K., \& Blume, B. D. (2017). The state of transfer of training research: Moving toward more consumer-centric inquiry. Human Resource Development Quarterly, 28(1), 17-28. https://doi.org/10.1002/hrdq.21278

Bandura, A. (1997). Self-Efficacy: The Exercise of Control. Worth Publishers, New York, NY.

Banville, D., Desrosiers, P., \& Genet-Volet, Y. (2000). Translating questionnaires and inventories using a cross-cultural translation technique. Journal of Teaching in Physical Education, 19(3), 374-387. https://doi.org/10.1123/jtpe.19.3.374

Bates, R., Holton III, E. F., \& Hatala, J. P. (2012). A revised learning transfer system inventory: Factorial replication and validation. Human Resource Development International, 15(5), 549-569. https://doi.org/10.1080/13678868.2012.726872

Bates, R., Kauffeld, S., \& Holton III, E. F. (2007). Examining the factor structure and predictive ability of the German-version of the Learning Transfer Systems Inventory. Journal of European Industrial Training, 31(3), 195-211. https://doi.org/10.1108/03090590710739278

Bhatti, M. A., Kaur, S., \& Battour, M. M. (2013). Training transfer and transfer motivation in the Malaysian banking sector. Global Business and Organizational Excellence, 33, 40-57. https://doi.org/10.1002/joe.21522

Blume, B. D., Ford, J. K., Baldwin, T. T., \& Huang, J. L. (2010). Transfer of training: A meta-analytic review. Journal of Management, 36, 1065-1105. https://doi.org/10.1177/0149206309352880

Bock, G. W., \& Kim, Y. G. (2002). Breaking the myths of rewards: an exploratory study of attitudes about knowledge sharing. Information Resources Management Journal (IRMJ), 15(2), 14-21. https://doi.org/10.4018/irmj.2002040102

Brislin, R.W. (1970). Back-translation for cross-cultural research. Journal of Cross-Cultural psychology, 1(3), 185-216. https://doi.org/10.1177/135910457000100301

Bryman, A., \& Bell, E. (2011). Business Study Methods. Oxford University Press, Oxford.

Burke, L. A., \& Hutchins, H. M. (2007). Training transfer: an integrative literature review. Human Resource Development Review, 6, 263-296. https://doi.org/10.1177/1534484307303035

Burke, L. A., \& Saks, A. M. (2009). Accountability in training transfer: adapting Schlenker's model of responsibility to a persistent but solvable problem. Human Resource Development Review, 8, 382-402. https://doi.org/10.1177/1534484309336732 
Chauhan, R., Ghosh, P., Rai, A., \& Kapoor, S. (2017). Improving transfer of training with transfer design: Does supervisor support moderate the relationship? Journal of Workplace Learning, 29(4), 268-285. https://doi.org/10.1108/JWL-08-2016-0079

Cheng, E. W. L., \& Hampson, I. (2008). Transfer of training: a review and new insights. International Journal of Management Reviews, 10, 327-341. https://doi.org/10.1111/j.1468-2370.2007.00230.x

Cheng, E. W. L., \& Ho, D. C. K. (1998). The effects of some attitudinal and organizational factors on transfer outcome. Journal of Managerial Psychology, 13, 309-317. https://doi.org/10.1108/02683949810219873

Cheng, E. W., Sanders, K., \& Hampson, I. (2015). An intention-based model of transfer of training. Management Research Review, 38(8), 908-928. https://doi.org/10.1108/MRR-05-2014-0107

Chiaburu, D. S., \& Marinova, S. V. (2005). What predicts skill transfer? An exploratory study of goal orientation, training self-efficacy and organizational supports. International Journal of Training and Development, 9(2), 110-123. https://doi.org/10.1111/j.1468-2419.2005.00225.x

Chiaburu, D. S., Van Dam, K., \& Hutchins, H. M. (2010). Social support in the workplace and training transfer: A longitudinal analysis. International Journal of Selection and Assessment, 18(2), 187-200. https://doi.org/10.1111/j.1468-2389.2010.00500.x

CIPD. (2015). Annual Survey Report. Chartered Institute of Personnel and Development, London.

Creswell, J. W. (2013). Study Design: Qualitative, Quantitative, and Mixed Methods Approaches. Sage, Thousand Oaks, CA.

Cromwell, S. E., \& Kolb, J. A. (2004). An examination of work/environment support factors affecting transfer of supervisory skills training to the workplace. Human Resource Development Quarterly, 15(4), 449-471. https://doi.org/10.1002/hrdq.1115

Davis, L. E., Ajzen, I., Saunders, J., \& Williams, T. (2002). The decision of African American students to complete high school: An application of the theory of planned behavior. Journal of Educational Psychology, 94, 810-819. https://doi.org/10.1037/0022-0663.94.4.810

Delgado, P. A. A. D. L. (2016). The United Arab Emirates case of economic success: The federal government economic policies (Doctoral Dissertation, Católica Porto Business School, Porto).

Facteau, J. D., Dobbins, G. H., Russell, J. E., Ladd, R. T., \& Kudisch, J. D. (1995). The influence of general perceptions of the training environment on pretraining motivation and perceived training transfer. Journal of Management, 21(1), 1-25. https://doi.org/10.1177/014920639502100101

Fitzgerald, C. G. (2002). Transfer of training and transfer climate: The relationship to the use of transfer maintenance strategies in an autonomous job context (Doctoral Dissertation, University of Connecticut, Storrs, CT).

Fitzgerald, C. G., \& Kehrhahn, M. T. (2003). Transfer of training in an autonomous job context (Unpublished paper). University of Connecticut, Storrs, CT.

Ford, J. K., \& Weissbein, D. A. (1997). Transfer of training: An updated review and analysis. Performance Improvement Quarterly, 10, 22-41. https://doi.org/10.1111/j.1937-8327.1997.tb00047.x

Ford, L. (2009). Improving training transfer. Industrial and Commercial Training, 41, 92-96. https://doi.org/10.1108/00197850910939135

Foxon, M. (1994). A process approach to the transfer of training. Part 2: Using action planning to facilitate the transfer of training. Australasian Journal of Educational Technology, 10(1), 1-18. https://doi.org/10.14742/ajet.2080

Friedman, S., \& Ronen, S. (2015). The effect of implementation intentions on transfer of training. European Journal of Social Psychology, 45(4), 409-416. https://doi.org/10.1002/ejsp.2114

Georgenson, D.L. (1982). The problem of transfer calls for partnership. Training and Development Journal, 36, 75-78.

Ghosh, P., Chauhan, R., \& Rai, A. (2015). Supervisor support in transfer of training: Looking back at past research. Industrial and Commercial Training, 47(4), 201-207. https://doi.org/10.1108/ICT-11-2014-0071

Gollwitzer, P. M. (1996). Benefits of Planning. In P. M. Gollwitzer, \& J. A. Bargh (Eds.), The Psychology of Action: Linking Cognition and Motivation to Behavior (pp. 287-312). Guilford Press, New York, NY. 
Gollwitzer, P. M., \& Sheeran, P. (2006). Implementation intentions and goal achievement: A met-analysis of effects and processes. Advances in Experimental Social Psychology, 38, 69-119. https://doi.org/10.1016/S0065-2601(06)38002-1

Govaerts, N., \& Dochy, F. (2014). Disentangling the role of the supervisor in transfer of training. Educational Research Review, 12, 77-93. https://doi.org/10.1016/j.edurev.2014.05.002

Govaerts, N., Kyndt, E., \& Dochy, F. (2018). The influence of specific supervisor support types on transfer of training: examining the mediating effect of training retention. Vocations and Learning, 11(2), 265-288. https://doi.org/10.1007/s12186-017-9190-y

Griffin, R. P. (2010). Means and ends: Effective training evaluation. Industrial and Commercial Training, 42, 220-225. https://doi.org/10.1108/00197851011048582

Grohmann, A., Beller, J., \& Kauffeld, S. (2014). Exploring the critical role of motivation to transfer in the training transfer process. International Journal of Training and Development, 18(2), 84-103. https://doi.org/10.1111/ijtd.12030

Grossman, R., \& Salas, E. (2011). The transfer of training: What really matters. International Journal of Training and Development, 15, 103-120. https://doi.org/10.1111/j.1468-2419.2011.00373.x

Gyimah, E. (2015). The effect of organizational climate on transfer of training. European Journal of Business and Management, 7(19), 137-146.

Hair Jr., J. F., Celsi, M., Money, A. H., Samouel, P., \& Page, M. J. (2016). Essentials of Business Research Methods (3rd ed.). Routledge. Armonk, NY: Sharpe.

Hair Jr., J. F., Hult, G. T. M., Ringle, C., \& Sarstedt, M. (2016). A Primer on Partial Least Squares Structural Equation Modeling (PLS-SEM). Sage, Thousand Oaks, CA.

Hair, J. F., Sarstedt, M., Ringle, C. M., \& Mena, J. A. (2012). An assessment of the use of partial least squares structural equation modeling in marketing research. Journal of the academy of marketing science, 40(3), 414-433. https://doi.org/10.1007/s11747-011-0261-6

Hair, J.F ., Sarstedt, M., Hopkins, L., \& Kuppelwieser, V. G. (2014). Partial least squares structural equation modeling (PLS-SEM) An emerging tool in business research. European Business Review, 26(2), 106-121. https://doi.org/10.1108/EBR-10-2013-0128

Holton III, E. F., Bates, R. A., \& Ruona, W. E. (2000). Development of a generalized learning transfer system inventory. Human resource development quarterly, $11(4), \quad 333-360$. https://doi.org/10.1002/1532-1096(200024)11:4<333::AID-HRDQ2>3.0.CO;2-P

Holton, E. F. (1996). The flawed four-level evaluation model. Human Resource Development Quarterly, 7, 5-21. https://doi.org/10.1002/hrdq.3920070103

Holton, E. F. (2005). Holton's evaluation model: New evidence and construct elaborations. Advances in Developing Human Resources, 7, 37-54. https://doi.org/10.1177/1523422304272080

Industry Report 2000. (2000). Training, 37(10), 45-48.

Jamieson, S. (2004). Likert scales: How to (ab) use them. Medical Education, 38(12), 1217-1218. https://doi.org/10.1111/j.1365-2929.2004.02012.x

Jun-Choi, H., \& Park, J.H. (2014). The relationship between learning transfer climates and innovation in public and private organizations in Korea. International Journal of Manpower, 35(7), 956-972. https://doi.org/10.1108/IJM-07-2012-0101

Kauffeld, S., \& Lehmann-Willenbrock, N. (2010). Sales training: Effects of spaced practice on training transfer. Journal of European Industrial Training, 34, 23-37. https://doi.org/10.1108/03090591011010299

Kavanagh, M. J. (1998). Transfer of training: A multi-stage model designed for practical use by organizations. Strategisches Euro-Management (pp. 301-321).

Kerlinger, F. N. (1979), Behavioral Study: A Conceptual Approach. Rinehart and Winston, New York, NY.

Khasawneh, S., Bates, R., \& Holton III, E. F. (2006). Construct validation of an Arabic version of the Learning Transfer System Inventory for use in Jordan. International Journal of Training and Development, 10(3), 180-194. https://doi.org/10.1111/j.1468-2419.2006.00253.x

Kim, J. H., \& Callahan, J. L. (2013). Finding the intersection of the learning organization and learning transfer. 
European Journal of Training and Development, 37, 183-200. https://doi.org/10.1108/03090591311301680

Kirkpatrick, D. L. (1959). Techniques for evaluating training programs. Journal of American Society of Training Directors, 13(3), 21-26.

Kraiger, K. (2002), Decision-based evaluation. In K. Kraiger (Ed.), Creating, Implementing, and Managing Effective Training and Development: State-of-the-Art Lessons for Practice (pp. 331-375). Jossey-Bass, San Francisco, CA.

Kraiger, K., McLinden, D., \& Casper, W. J. (2004). Collaborative planning for training impact. Human Resource Management, 43(4), 337-351. https://doi.org/10.1002/hrm.20028

Krejcie, R. V., \& Morgan, D. W. (1970). Determining sample size for research activities. Educational and Psychological Measurement, 30(3), 607-610. https://doi.org/10.1177/001316447003000308

Lunenburg, F. C., \& Irby, B. J. (2008). Writing a successful thesis or dissertation: Tips and strategies for students in the social and behavioral sciences. Corwin press.

Merriam, S. B., \& Leahy, B. (2005). Learning transfer: a review of the research in adult education and training. PAACE Journal of Lifelong Learning, 14(1), 1-24.

Nikandrou, I., Brinia, V., \& Bereri, E. (2009). Trainee perceptions of training transfer: an empirical analysis. Journal of European Industrial Training, 33, 255-270. https://doi.org/10.1108/03090590910950604

Norman, G. (2010). Likert scales, levels of measurement and the "laws" of statistics. Advances in Health Sciences Education, 15(5), 625-632. https://doi.org/10.1007/s10459-010-9222-y

Pham, N. T., Segers, M. S., \& Gijselaers, W. H. (2013). Effects of work environment on transfer of training: empirical evidence from Master of Business Administration programs in Vietnam. International Journal of Training and Development, 17(1), 1-19. https://doi.org/10.1111/j.1468-2419.2012.00417.x

Piaw, C. Y. (2012). Mastering research methods. Malaysia: McGraw-Hill.

Posthuma, R. A., \& Dworkin, J. B. (2000). A behavioral theory of arbitrator acceptability. International Journal of Conflict Management, 11(3), 249-266. https://doi.org/10.1108/eb022842

Rangel, B., Chung, W., Harris, T. B., Carpenter, N. C., Chiaburu, D. S., \& Moore, J. L. (2015). Rules of ePhamgement: the joint influence of trainer expressiveness and trainee experiential learning style on ePhamgement and training transfer. International Journal of Training and Development, 19(1), 18-31. https://doi.org/10.1111/ijtd.12045

Roscoe, J. T. (1975). Fundamental Research Statistics for the Behavioral Sciences. Holt, Rinehart and Winston, New York, NY.

Scaduto, A., Lindsay, D., \& Chiaburu, D. S. (2008). Leader influences on training effectiveness: motivation and outcome expectation processes. International Journal of Training and Development, 12(3), 158-170. https://doi.org/10.1111/j.1468-2419.2008.00303.x

Schumacker, R. E., \& Lomax, R. G. (2016). A Beginner's Guide to Structural Equation Modeling. Routledge, New York, NY.

Sekaran, U., \& Bougie, R. (2013). Research Methods for Business: A Skill-Building Approach (6th ed.). John Wiley \& Sons, West Sussex.

Tesluk, P. E., Farr, J. L., Mathieu, J. E., \& Vance, R. J. (1995). Generalization of employee involvement training to the job setting: Individual and situational effects. Personnel Psychology, 48(3), 607-632. https://doi.org/10.1111/j.1744-6570.1995.tb01773.x

Tracey, J. B., Tannenbaum, S. I., \& Kavanagh, M. J. (1995). Applying trained skills on the job: the importance of the work environment. Journal of Applied Psychology, 80, 239-252. https://doi.org/10.1037/0021-9010.80.2.239

Ubed, R. S. (2017). The relationship between management support, training motivation, intention to transfer, affective reaction, utility reaction, supervisor support, and level III and IV leadership training transfer: A case in Indonesian ministry of finance. INFO ARTHA, 2, 1-19.

Van den Bossche, P., \& Segers, M. (2013). Transfer of training: Adding insight through social network analysis. Educational Research Review, 8, 37-47. https://doi.org/10.1016/j.edurev.2012.08.002

Van der Locht, M., van Dam, K., \& Chiaburu, D. S. (2013). Getting the most of management training: The role 
of identical elements for training transfer. Personnel Review, 42(4), 422-439. https://doi.org/10.1108/PR-05-2011-0072

Velada, R., Caetano, A., Michel, J. W., Lyons, B. D., \& Kavanagh, M. J. (2007). The effects of training design, individual characteristics and work environment on transfer of training. International Journal of Training and Development, 11, 282-294. https://doi.org/10.1111/j.1468-2419.2007.00286.x

Wiethoff, C. (2004). Motivation to learn and diversity training: Application of the theory of planned behavior. Human Resource Development Quarterly, 15(3), 263-278. https://doi.org/10.1002/hrdq.1103

Wong, K. K. K. (2013). Partial least squares structural equation modeling (PLS-SEM) techniques using SmartPLS. Marketing Bulletin, 24(1), 1-32.

Xiao, J. (1996). The relationship between organizational factors and the transfer of training in the electronics industry in Shenzhen, China. Human Resource Development Quarterly, 7(1), 55-73. https://doi.org/10.1002/hrdq.3920070107

\section{Copyrights}

Copyright for this article is retained by the author(s), with first publication rights granted to the journal.

This is an open-access article distributed under the terms and conditions of the Creative Commons Attribution license (http://creativecommons.org/licenses/by/4.0/). 